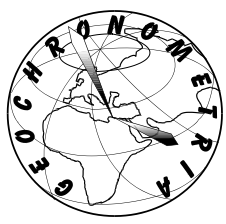

Conference Proceedings of the $12^{\text {th }}$ International Conference "Methods of Absolute Chronology" May 11-13 ${ }^{\text {th }}$, 2016, Gliwice-Paniówki, Poland

\title{
THE HISTORY OF THE SEDIMENTATION PROCESSES AND HEAVY METAL POLLUTION IN THE CENTRAL DANUBE DELTA (ROMANIA)
}

\author{
RÓBERT-CSABA BEGY ${ }^{1,2}$, SZABOLCS KELEMEN ${ }^{1}$, HEDVIG SIMON ${ }^{1}$ and CLAUDIU TĂNĂSELIA ${ }^{3}$ \\ ${ }^{1}$ Babeş-Bolyai University, Faculty of Environmental Science and Engineering, Fântânele 30, 400294,Cluj-Napoca, Romania \\ ${ }^{2}$ Interdisciplinary Research Institute on Bio-Nano-Sciences, Babeș-Bolyai University, \\ Treboniu Laurean 42,400271 Cluj-Napoca, Romania \\ ${ }^{3}$ INCDO-INOE 2000 Research Institute for Analytical Instrumentation (ICIA), Cluj-Napoca, Romania
}

Received 30 June 2016

Accepted 20 March 2018

\begin{abstract}
The aim of this study was to investigate the effects of the Iron Gates (IG) hydroelectric power station on the Danube Delta sediment dynamics, and to assess the heavy metal concentrations and pollution in a typical Central Danube Deltaic lake.

Eight sediment cores were analysed. The total ${ }^{210} \mathrm{~Pb}$ content was measured with ${ }^{210} \mathrm{Po}$ using alpha spectrometry, and the supported ${ }^{210} \mathrm{~Pb}\left({ }^{226} \mathrm{Ra}\right)$ and ${ }^{137} \mathrm{Cs}$ were measured by gamma spectrometry. The age depth model was derived by applying the ${ }^{210} \mathrm{~Pb}$ dating method, and for the calculation of the ages and the sedimentation rates the CRS model was used.

The sedimentation rates can be divided into four periods: 1940-1972, 1972-1980, 1972-1989 and 1989-2013. In the case of Lake Iacob in the first period, the average sedimentation rate was $0.418 \mathrm{~g} / \mathrm{cm}^{2} \mathrm{y}$, while in the second it slowly decreased to $0.376 \mathrm{~g} / \mathrm{cm}^{2} \mathrm{y}$. In the third period, the sedimentation fell to $0.209 \mathrm{~g} / \mathrm{cm}^{2} \mathrm{y}$, which means the retention of $27.3 \%$ of the sediment by the IG dam. In the case of Lake Isac the changes were more visible: in the first period the average sedimentation rate was $0.446 \mathrm{~g} / \mathrm{cm}^{2} \mathrm{y}$, while in the second it decreased to $0.197 \mathrm{~g} / \mathrm{cm}^{2} \mathrm{y}$, which means a $42.35 \%$ retention of sediment. In the last period, in both cases, a high increase in the sedimentation rate is shown: $0.677 \mathrm{~g} / \mathrm{cm}^{2} \mathrm{y}$ for Lake Iacob and $0.715 \mathrm{~g} / \mathrm{cm}^{2} \mathrm{y}$ for Lake Isac. The heavy-metal concentrations for As, $\mathrm{Co}, \mathrm{Cr}$ and $\mathrm{Ni}$ show decreasing and $\mathrm{Hg}$ increasing tendencies, while $\mathrm{Cd}$ and $\mathrm{Pb}$ show constant values of $310 \pm 12 \mathrm{ppb}$ and $9 \pm 1 \mathrm{ppm}$ respectively.
\end{abstract}

Keywords: geochronology, ${ }^{210} \mathrm{~Pb}\left({ }^{210} \mathrm{Po}\right)$ dating method, sediment dynamics, heavy metals.

\section{INTRODUCTION}

The ${ }^{210} \mathrm{~Pb}\left(\mathrm{~T}^{1} / 2=22.3 \mathrm{y}\right)$ radioactive-dating method is the most frequently and reliably used method to calculate short-term sediment deposition and sedimentation rates

Corresponding author: R.C. Begy

e-mail: robert.begy@ubbcluj.ro
$(0-200$ y) in oceans, estuaries, rivers and lakes (Humphries, 2010), because of its relative insolubility and long half-life. As a natural radioactive element in the ${ }^{238} \mathrm{U}$ decay chain, it is present in both soils (sediments) and the atmosphere. In sediments ${ }^{210} \mathrm{~Pb}$ has two sources: the supported ${ }^{210} \mathrm{~Pb}$, which is continuously decaying in the sediments from its parent radionuclide, ${ }^{226} \mathrm{Ra}$, with which it is assumed to be in secular equilibrium, and the unsupported ${ }^{210} \mathrm{~Pb}$, formed by the emanation of ${ }^{222} \mathrm{Rn}$ from soils, which then decays into a series of short-lived radionu- 
clides, and which are finally deposited in the catchment area and directly in the lake.

Studying the natural sediment deposits makes it possible to highlight the historic modifications (Alvisi and Dinelli, 2010) of the major hydrological processes and the erosion of soils due to vegetal surface overexploitation, deforestation/reforestation, or changes in agricultural techniques (Begy et al., 2015a). The layers can also provide information about possible atmospheric organic pollutants, heavy metals (Qi et al., 2010) or radioactive emissions from nuclear installations. Estimates of sediment accumulation rates, and the significance of heavy metal inputs (Steiner et al., 2000; Al-Masri et al., 2002) from anthropogenic activities relative to natural inputs, were the subjects of many studies of lakes (Larsen et al., 2010; Schneider et al., 2014; Baskaran et al., 2015), river deltas (Xu et al., 2008 and Hou et al., 2014), lagoons (Niencheski et al., 2014) and seas (Sert et al., 2012; Szmytkiewicz and Zalewska, 2014).

This work presents the results of the first detailed study on the sedimentation processes and the associated morphological changes in the Iacob and Isac Lakes, and the Danube Delta, using the ${ }^{210} \mathrm{~Pb}$ radiometric dating method. The sedimentation rate in the Iacob and Isac lacustrine units was determined in order to investigate the temporal variation of the Danube River's solid discharges, and to reflect the variations in the sediment levels caused by flooding or human activities. Additionally, ${ }^{137} \mathrm{Cs}$ measurements provided a useful independent time marker for validating the data obtained from the ${ }^{210} \mathrm{~Pb}$ dating. In the sediment of Lake Iacob the heavy metal concentrations were analysed to reconstruct the pollution history.

\section{THE STUDY SITE}

The Iacob and Isac Lakes can be found in the first part of the marine Danube Delta, south from the Sulina
Branch, but without direct connections to it. The lake banks are marked by vegetation formed mainly of grasses belonging to the Poaceae family (reeds), facilitating permeability and water exchange with the other specific limnophilous units. The phytoplankton and zooplankton levels in both lakes are high, and the development of green-blue algae is favourable (Oosterberg et al., 2000).

Lake Iacob is part of the Rosu-Puiu lake complex, and has a total surface area of 2208 ha (600 ha open water, 360 ha potentially floating reed and 1248 ha inundated reed). The lake is $4.6 \mathrm{~km}$ long, and $1.6 \mathrm{~km}$ wide through a flow lake. It is $3.63 \mathrm{~m}$ deep and situated at an altitude of $1.8 \mathrm{~m}$. The basin of Lake Iacob consists of a depression between two elongated lakes in the NE-SW direction, and the formation which marks the initial propagation stages of the Sulina delta lobe ( $c a .3300$ years BC). In the present, the main pathway of communication and sediment exchange between this lake, and the rest of the deltaic system is represented by a secondary channel situated in the south of the lake. This starts at the Caraorman Channel, which was built in the 1930-1940 period (Oosterberg et al., 2000) in the Rosu-Puiu complex, and is seconded by two other lower discharge channels of the Sulina Branch.

Lake Isac is a border lake with a total area of $2560 \mathrm{ha}$, of which 1020 ha is open water, 260 ha potentially floating reed, and 1280 ha inundated reed. Lake Isac is $4.2 \mathrm{~km}$ long and $3.1 \mathrm{~km}$ wide, its depth is $2.4 \mathrm{~m}$, and it is situated at an altitude of $1.32 \mathrm{~m}$. The basin of Lake Isac is part of the Uzlina and Isac Lakes system in the Grogova-Uzlina complex. The Lake has three channel entries: one in the NE part, one in the NW part and the last one in the southern part of the lake. This has an indirect connection to the Sf. Gheorghe Branch through Lake Uzlina. This channel was built between 1941 and 1951 (Oosterberg et al., 2000), while the NE and NW channels are linked to each other, and start at the Caraorman Channel (Fig. 1), being connected to the high water and sediment discharge into the Sulina Branch, and have a constant water travel time
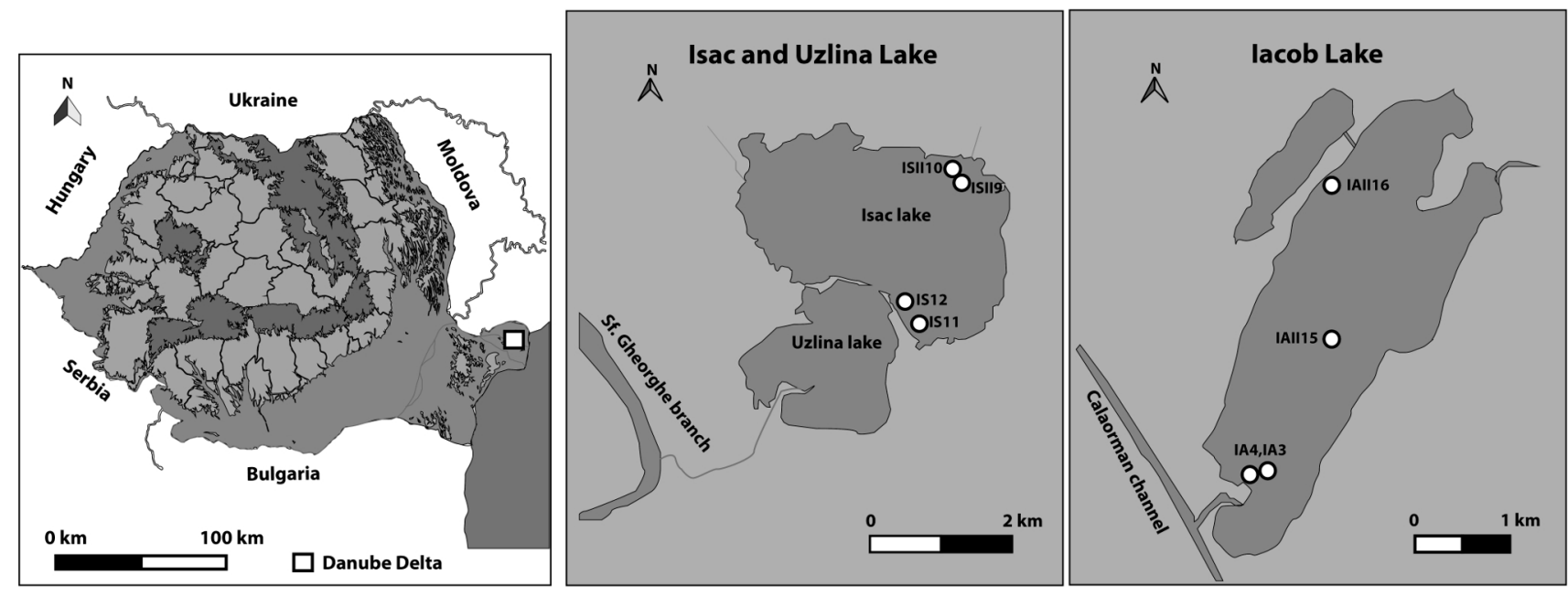

Fig. 1. Lake lacob and the locations of the sampled sediment cores. 
of 1 day. In addition to its favourable location in the Central Danube Delta, Lake Iacob is ideal for heavy metal pollution determination typical for the Central Danube Delta.

Four sediment cores with lengths in the $42-77 \mathrm{~cm}$ range were taken from each lake using a gravity corer during two sampling campaigns: IA3 $\left(45^{\circ} 07^{\prime} 49.3^{\prime \prime} \mathrm{N}\right.$,

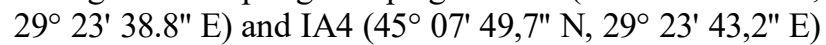
and, respectively, IS11 (45 $\left.05^{\circ} 51.7^{\prime \prime} \mathrm{N}, 23^{\circ} 16^{\prime} 35.3^{\prime \prime} \mathrm{E}\right)$ and IS12 (45 $\left.05^{\circ} 57.4^{\prime \prime} \mathrm{N}, 23^{\circ} 16^{\prime} 28.7^{\prime \prime} \mathrm{E}\right)$, were taken in November 2013, while IAII15 $\left(45^{\circ} 8^{\prime} 9,50^{\prime \prime} \mathrm{N}\right.$, $\left.29^{\circ} 24^{\prime} 3,10^{\prime \prime} \mathrm{E}\right)$ and IAII16 (45 9' 8,70"N, $\left.29^{\circ} 24^{\prime} 2,70^{\prime \prime} \mathrm{E}\right)$ and, respectively, ISII9 (45 06' 55.9" N, $\left.29^{\circ} 17^{\prime} 36.7^{\prime \prime} \mathrm{E}\right)$ and ISII10 ( $\left.45^{\circ} 07^{\prime} 01.5^{\prime \prime} \mathrm{N}, 29^{\circ} 17^{\prime} 36.7^{\prime \prime} \mathrm{E}\right)$, were taken in August 2014.

\section{MATERIALS AND METHODS}

Each of the sediment cores was sub-sampled into $1-3 \mathrm{~cm}$ slices. The sub-samples $(2-5 \mathrm{~g})$ of the sliced core sections were used for measuring the physical characteristics of the sediment sample, including bulk density, water content and porosity, as described in Saravana Kumar et al., 1999. The porosity was calculated from the fluid capacity of the interconnected pores. By dividing the pore volume by the bulk volume, the porosity in percent terms can be determined (Manger et al., 1963).

The remaining quantity of each sub-sample was dried in a drying oven at $75^{\circ} \mathrm{C}$, until a constant mass was obtained. After grinding, sieving and homogenisation, the samples were stored in the laboratory for $\alpha$ and $\gamma$ spectrometric measurements. LOI (Loss on Ignition) measurements were performed to determine the organic mass $(\mathrm{OM})$ and carbonate content (IOC) at $350^{\circ} \mathrm{C}$ and $750^{\circ} \mathrm{C}$ respectively, the sum of the two (OM and IOC) giving the total carbon content (TOC).

\section{${ }^{210} \mathrm{~Pb}$ chronology}

\section{Gamma spectrometry}

Samples for gamma spectrometric measurements were placed in cylindrical aluminium boxes $(6 \mathrm{~cm}$ diameter and $1 \mathrm{~cm}$ height) sealed with aluminium tape, to avoid the ${ }^{222} \mathrm{Rn}$ loss. For the gamma spectrometric measurements $\sim 15-20 \mathrm{~g}$ dried sediment samples were used. The sealed boxes were stored for 3 weeks in order to reach the radioactive equilibrium between ${ }^{226} \mathrm{Ra}$ and its progenies.

High resolution $\gamma$ spectrometric analyses were carried out using an ORTEC GMX type HPGe detector $(0.878 \mathrm{keV}$ FWHM at $5.9 \mathrm{keV}$ and $1.92 \mathrm{keV}$ at $1.33 \mathrm{MeV}$ with a relative efficiency of $34.2 \%$ and a $0.5 \mathrm{~mm} \mathrm{Be}$ window) for the determination of the supported ${ }^{210} \mathrm{~Pb}$. The ${ }^{226} \mathrm{Ra}$ was measured via ${ }^{222} \mathrm{Rn}$ and its short life products ${ }^{214} \mathrm{~Pb}$ (using the $295.1 \mathrm{keV}$ and $352.0 \mathrm{keV}$ energy photo-peaks) and ${ }^{214} \mathrm{Bi}$ (using the $609.3 \mathrm{keV}$ photo-peak) (Moor, 1984); for ${ }^{137} \mathrm{Cs}$ the $661.7 \mathrm{keV}$ energy gamma line was used. To determine the activity concentration of the radionuclides the relative method was applied using the IAEA-385 Irish Sea sediment (for the ${ }^{226} \mathrm{Ra}$ determination) and IAEA-375 (for the ${ }^{137} \mathrm{Cs}$ determination) reference materials. The minimum acquisition time for all measurements was $80.000 \mathrm{~s}$.

\section{Alpha spectrometry}

The total ${ }^{210} \mathrm{~Pb}$ content was measured via alpha spectrometry, using ${ }^{210} \mathrm{Po}$, by the chemical separation of the Polonium isotope from the sediment matrix and from the other alpha emitters. For each $0.5 \mathrm{~g}$ of dried homogenised sediment sample, $0.3 \mathrm{ml}$ of ${ }^{209} \mathrm{Po}$ tracer (with $100 \mathrm{mBq} / \mathrm{ml}$ activity) was added, in order to determine the chemical yield. Acid digestion was carried out by using $20 \mathrm{ml}$ of concentrated $\mathrm{HNO}_{3}$ in three steps; each time the sample was evaporated until near-dryness. After these, $20 \mathrm{ml}$ of concentrated $\mathrm{HCl}$ in three doses was used. For the elimination of organic matter some drops of $\mathrm{H}_{2} \mathrm{O}_{2}$ were added. In order to eliminate the acids, $20 \mathrm{ml}$ of distilled water was added and evaporated until neardryness. The last procedure was repeated three times. The ${ }^{210}$ Po sources were prepared by spontaneous deposition on the surface of high Ni content stainless steel discs in an $\mathrm{HCl}$ acid medium with $0.5-1 \mathrm{pH}$ for $3 \mathrm{~h}$ at $85^{\circ} \mathrm{C}$. Interferents ( $\mathrm{Fe}$ - ions) were eliminated by adding ascorbic acid for the formation of iron complexes (Begy et al., $2015 \mathrm{~b}$ ). The obtained sources were measured by an ORTEC SOLOIST $900 \mathrm{~mm}^{2}$ PIPS detector (19 keV resolution) and an ASPEC- 92 data acquisition system.

The constant rate of the ${ }^{210} \mathrm{~Pb}$ supply (CRS) model was used to determine the ages and sedimentation rates of each sub-sampled sediment layer. This model is used if the sediment accumulation is not constant over time (deltaic lakes showing dynamic changes over short periods), but if it can be presumed that the rate of the unsupported

${ }^{210} \mathrm{~Pb}$ deposition is permanent (Appleby et al., 2001).

\section{Heavy metal analyses}

In Lake Iacob the heavy metal concentrations were measured using an Inductively Coupled Plasma Mass Spectrometer of the SCIEX Perkin-Elmer Elan DRC II type. Measurements were made for $\mathrm{Li}, \mathrm{Mg}, \mathrm{Al}, \mathrm{K}, \mathrm{Cr}$, $\mathrm{Mn}, \mathrm{Fe}, \mathrm{Co}, \mathrm{Ni}, \mathrm{Cu}, \mathrm{Zn}, \mathrm{As}, \mathrm{Cd}, \mathrm{Hg}$ and $\mathrm{Pb}$. For the heavy metal determination the exact measurement method described in Baceva et al., 2011 was used.

\section{RESULTS AND DISCUSSION}

\section{The physical parameters}

\section{Lakes Iacob and Isac}

Hakanson (1977) observed a correlation between the $\mathrm{OM}$ and water content of the sediments when analysing the Swedish Lake Ekoln. This connection is apparent in the sediments of Lakes Iacob and Isac, the exception being the IA 3 core in the case of Lake Iacob, where the 
water content does not increase in the same manner as the $\mathrm{OM}$, probably because of the compaction of the sediment (Fig. 2). Where the water content and the porosity did not correlate with the OM quantity, the deposition of inorganic matter was higher than that of the OM (Fig. 3). Because the pressure in the upper layers was lower than that of the lower ones, the porosity and water content of the sediments (the first $15 \mathrm{~cm}$ in IAII 15 is $75 \%$ ) was relatively high, despite the OM content's being low (the first $15 \mathrm{~cm}$ in IAII15 is $2 \%$ ). This was also influenced by the location of the sampling point. Although the water content of IAII 15 shows an increase from $44 \%$ to $80 \%$ in the first $34 \mathrm{~cm}$, this was followed by a decrease in the next $72 \mathrm{~cm}$. The water and OM are correlated in Lake Isac, the exception being the first $10 \mathrm{~cm}$ of the ISIII 10 core where the OM was on average $7 \%$, and the water content $73 \%$, where the same process took place as in the case of IAII15 (Figs. 4 and 5).

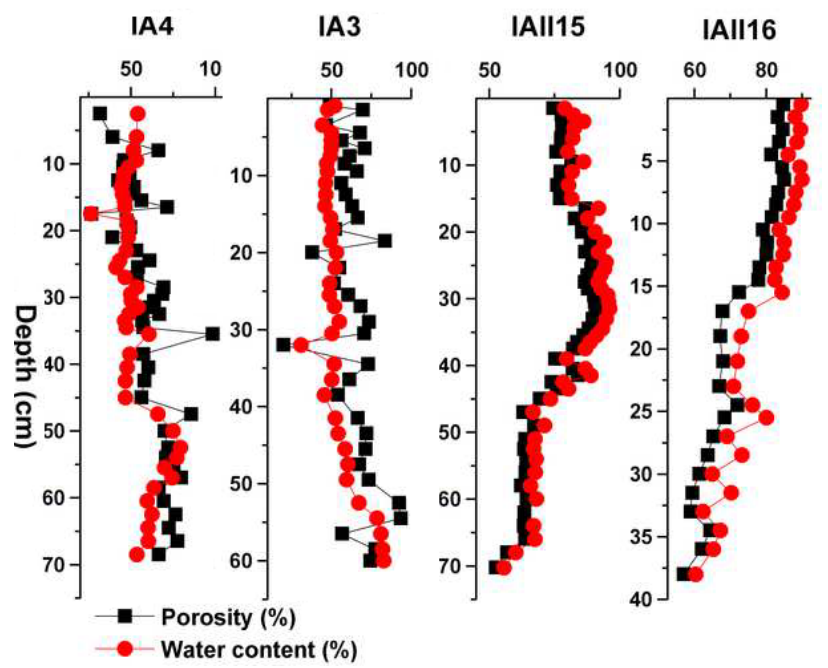

Fig. 2. The water content and porosity of Lake lacob cores.

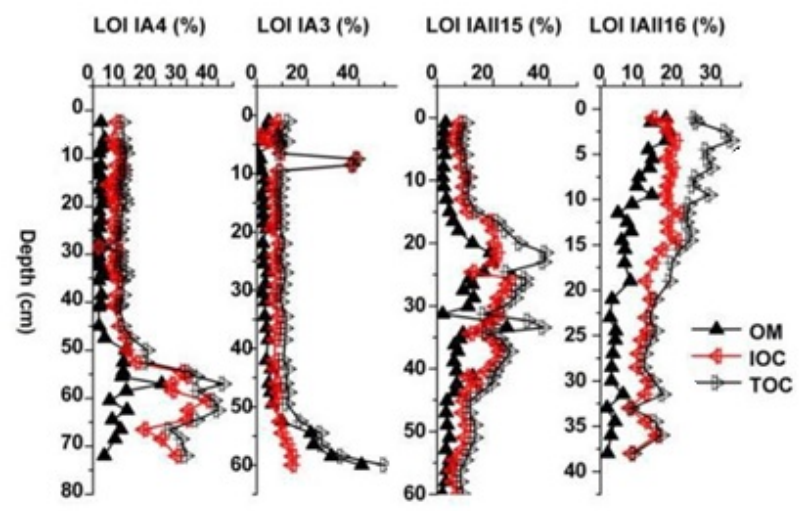

Fig. 3. The LOI measurements for the Lake lacob samples.

\section{${ }^{226} \mathrm{The} \mathrm{Ra}$ and ${ }^{210} \mathrm{~Pb}$ concentrations}

\section{Lake Iacob}

The mean ${ }^{226} \mathrm{Ra}$ concentration had an average of $20 \pm 2 \mathrm{~Bq} / \mathrm{kg}$ in the cases of IA3, IA4 and IAII15, while in the case of IAII15 it was only $15 \pm 2 \mathrm{~Bq} / \mathrm{kg}$. These values were lower than normal for $25-45 \mathrm{~Bq} / \mathrm{kg}$ (United
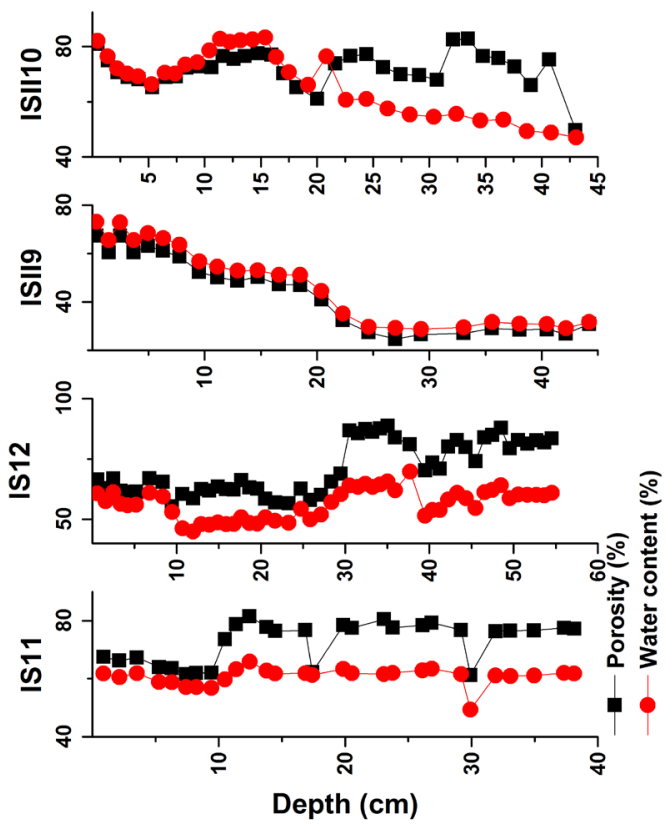

Fig. 4. The water content and porosity of the Lake Isac cores.
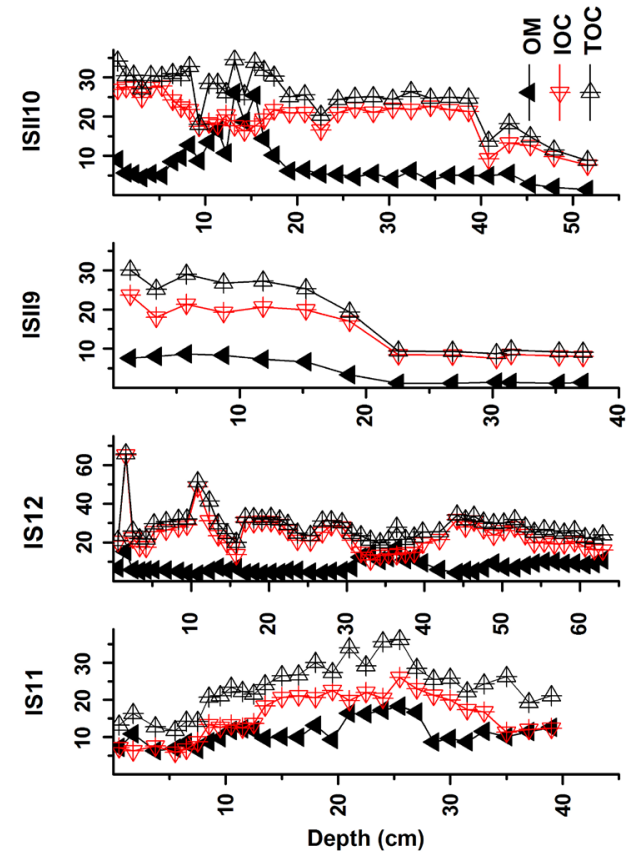

Fig. 5. The LOI measurements of the Lake Isac cores. 
Nations, 2008) for the supported ${ }^{210} \mathrm{~Pb}$ concentration because the ${ }^{226} \mathrm{Ra}$ was dissolved from the sediment due to the long transport route.

The ${ }^{210} \mathrm{~Pb}$ concentration decreased according to the law of disintegration, some perturbation being visible throughout the sediment cores (Fig. 6). The dating horizons were taken at $49 \mathrm{~cm}$ for IA3, at $55 \mathrm{~cm}$ for IA4, at $69 \mathrm{~cm}$ for IAII1 15 and at $37 \mathrm{~cm}$ for IAII16.

\section{Lake Isac}

In the case of IS12 and ISII9, the ${ }^{226}$ Ra concentration had an average of $30 \pm 4 \mathrm{~Bq} / \mathrm{kg}$, while in the case of IS11 and ISII10 this value was lower: $13 \pm 2 \mathrm{~Bq} / \mathrm{kg}$ (Fig. 7). The latter two sampling points were in the proximity of

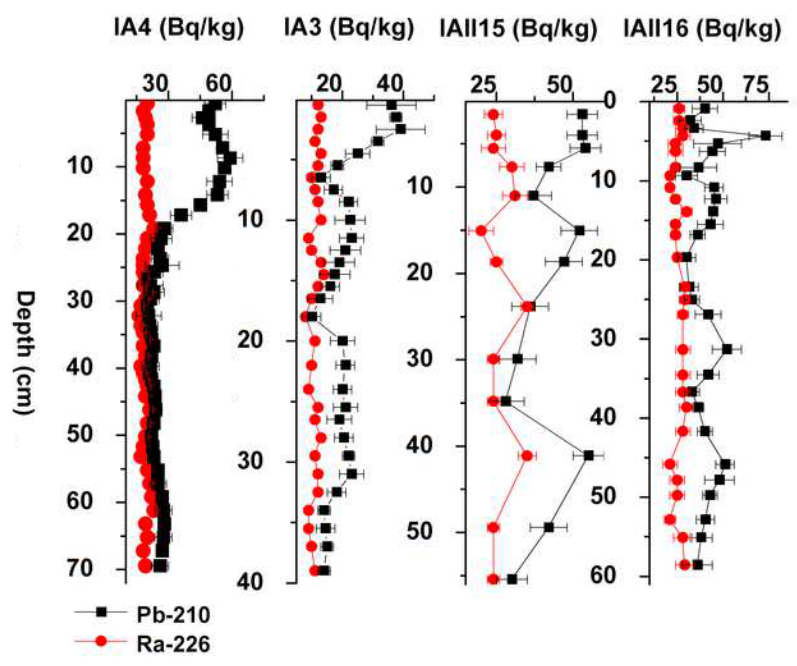

Fig. 6. The ${ }^{226} \mathrm{Ra}$ and ${ }^{210 \mathrm{~Pb}}$ concentrations of the Lake lacob cores.

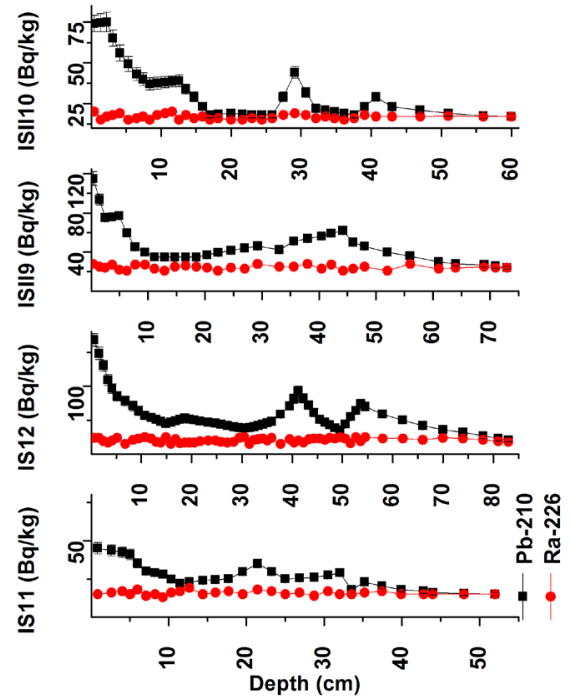

Fig. 7. The ${ }^{226} \mathrm{Ra}$ and210 $\mathrm{Pb}$ concentrations of the Lake Isac cores. the inflow channels and a greater ${ }^{226}$ Ra quantity could be dissolved. The dating horizons were taken at $34 \mathrm{~cm}$ for IS11, at $75 \mathrm{~cm}$ for IS12, at $65 \mathrm{~cm}$ for ISII9 and at $51 \mathrm{~cm}$ for ISII10.

\section{Age depth models of the sediment cores}

\section{Iacob Lake}

A comparison of the age distributions as correlated with the depth of the distinct sediment cores is shown in Fig. 8. It is clear that the deposed sediment quantity is proportional with the consistency of the age/depth function. For example in the IAII15 core the period of $19-55 \mathrm{~cm}$ shows ages of $1976 \pm 5 \mathrm{y}$ and a high sedimentation rate. Similar decreasing tendencies are apparent in the IA 3 and IA4 cores taken from each other's proximity in order to examine the sampling technique, which prove the consistency of the sampling procedure.

In all cases ${ }^{137} \mathrm{Cs}$ measurements were taken to validate the determined ages for the sediment layers. In Fig. 9 the two peaks for 1986 (the Chernobyl nuclear accident) and, respectively, 1963 (nuclear weapon tests) are visible, while the ages correspond to the obtained data resulting from the CRS model calculations. It is noticeable that the two ${ }^{137} \mathrm{Cs}$ peaks have similar activities, although the values for Chernobyl should be higher. This is due to the fact that the radioactive cloud of the Chernobyl nuclear accident spread mostly throughout central Romania, and the eastern part of Germany and Austria, where the Danube has parts of its catchment area.

The ${ }^{137} \mathrm{Cs}$ contamination originating from the Chernobyl nuclear accident is relatively low. However, the thermonuclear weapon test with maximum ${ }^{137} \mathrm{Cs}$ contamination in 1963 caused general, evenly spread, contamination throughout the entire catchment area.

From the sediment dynamics point of view, the sampling points situated in the vicinity of the main inflow

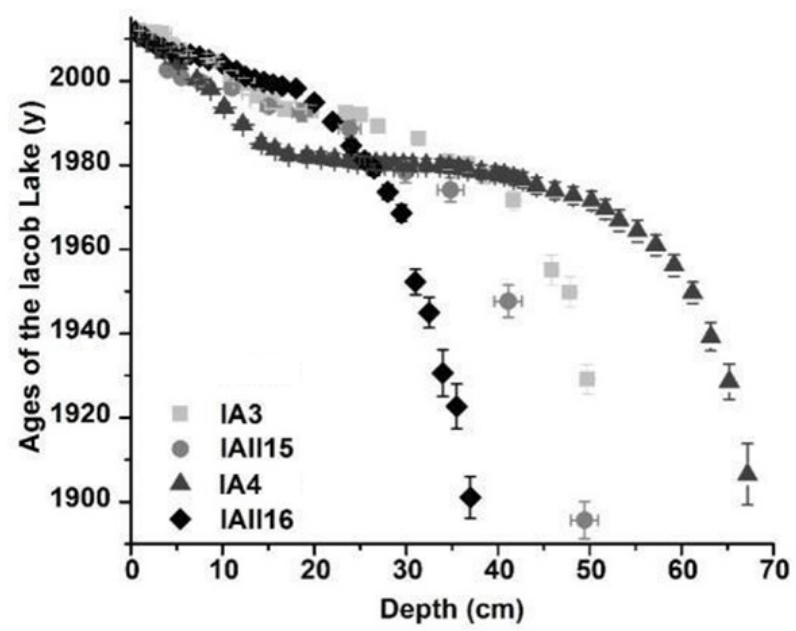

Fig. 8. The ages of the Lake lacob cores. 


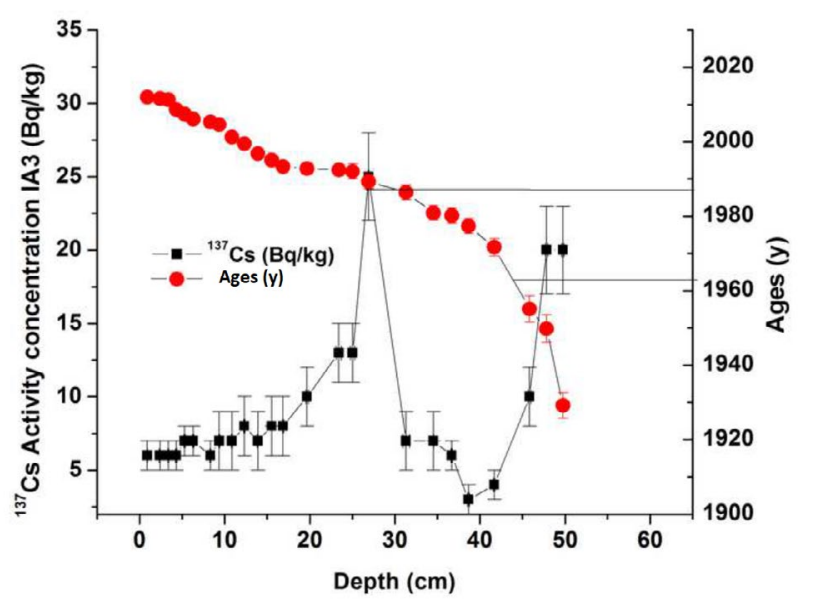

Fig. 9. The ${ }^{137} \mathrm{Cs}$ activity concentrations in the IA3 core.

channel and the one situated at the secluded shore show similar increases in cumulative mass (Fig. 10), reaching values in the $27-32 \mathrm{~g} / \mathrm{cm}^{2} \mathrm{y}$ range, while the one situated in the middle of the lake (IAII15) receives the least quantity of sediment $\left(17 \mathrm{~g} / \mathrm{cm}^{2} \mathrm{y}\right)$.

\section{Lake Isac}

Lake Isac has a high biomass content, and the development of algae types is favourable in the lake. Also, there is intense vegetation in the areas of the sampled cores, the OM content being commensurately high in the sediment.

The ages decrease similarly in the case of the IS11 and ISIII0 in the first $15 \mathrm{~cm}$, the two cores having a similar OM content, meaning that in the last 15 years the sediment has been deposited uniformly in the two sampling areas, the decomposing vegetation having had a

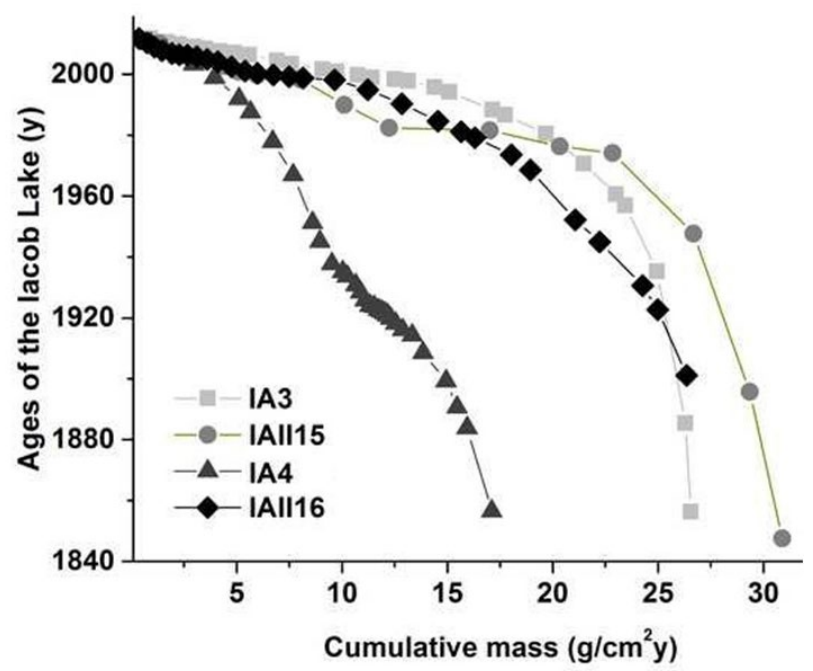

Fig. 10. The cumulative masses of the Lake lacob cores. dominant role. After the first $15 \mathrm{~cm}$ of the ISII10 core, a plateau is visible, which points to a great influx of sediment over a 2 year time span, and correlates with the OM content of the sediment core. This is also visible in the ISII9 core, where the extent of the compaction decreases with the OM content. In IS12, a compaction, together with the increase of OM, is also evident. The sediment layer corresponding to 1920 can be found at the $35-60 \mathrm{~cm}$ depth. The most sediment was deposited in the area of the IS12 core, which points to greater exposure.

The exposure of the sampled cores can be shown with the cumulative mass in accordance with the obtained ages. The most sediment is deposited in the areas of the IS12 and ISII10 sampling points, because of their proximity to the channel entrances, while IS11 and ISII9 are further away (Fig. 12).

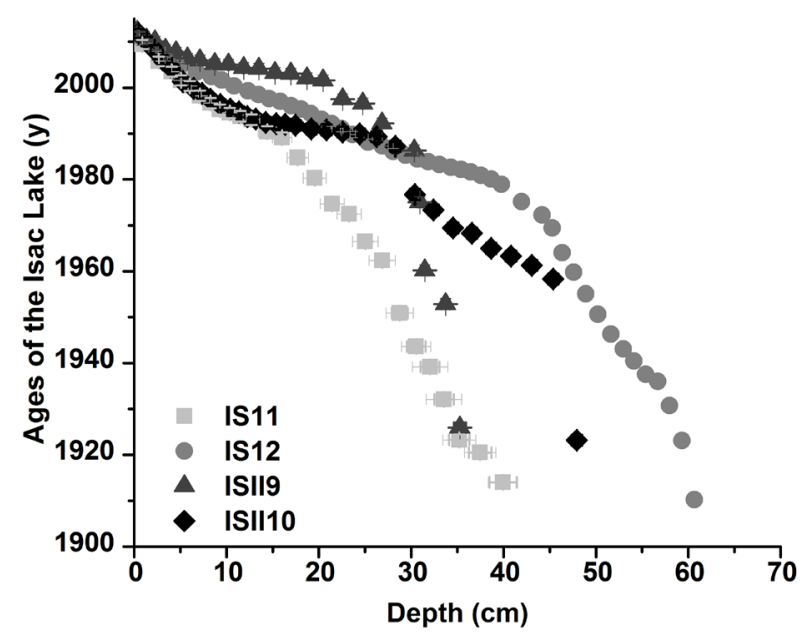

Fig. 11. The ages of the Lake Isac cores.

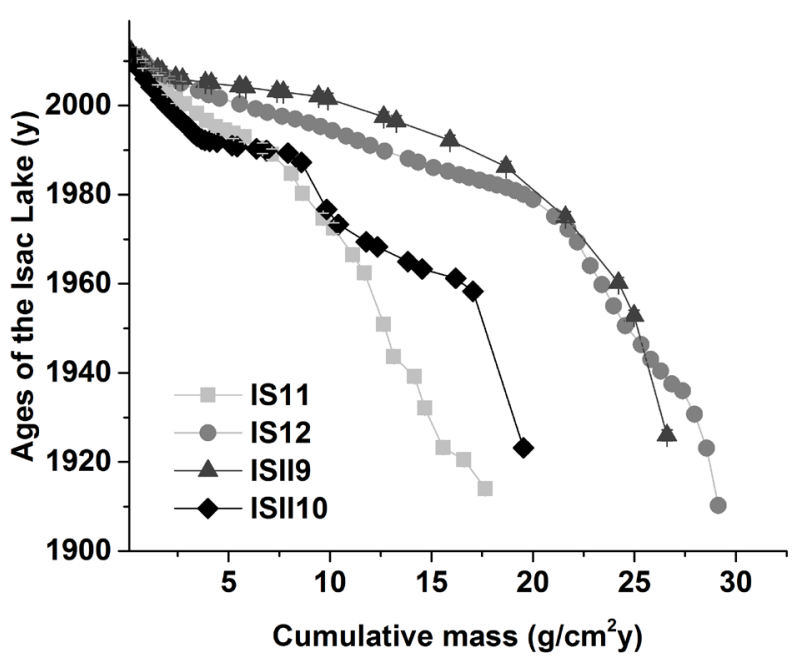

Fig. 12. The cumulative masses of the Lake Isac cores. 


\section{Sedimentation rates}

\section{Lake Iacob}

Analysing the sedimentation of IA3, four peaks are evident, providing information about the past hydrological events, i.e. the floods of 1980, 1991-1993, 2004 and 2011. The deposited sediment quantity and its velocity show that the 1991-1993 flooding was the most significant. The values for mass sedimentation exceed $2.2 \pm 0.09 \mathrm{~g} / \mathrm{cm}^{2} \mathrm{y}$ (Fig. 13). The 2004 and 2011 peaks were also the consequences of major floods, with peak discharges of $10,800 \mathrm{~m}^{3} / \mathrm{s}$ and, respectively, $10,200 \mathrm{~m}^{3} / \mathrm{s}$. Similar four sedimentation peaks were measured by Babic Mladenovic and his team (Babic Mladenovic et al., 2013) in the suspended sediment behind Iron Gate 2. Compared with IA3, IA4 shows three maximum values: in 1974, 1980 and 1998. Although the above mentioned cores were taken in close proximity, and the decreases in the ages in accordance with depth, shows a similar trend, the correlation between the peaks visible in the sedimentation rate is not conclusive. This might be due to the fact that the sectioning of the sub-samples of the two cores was made differently, IA3 being cut into smaller layers, so its resolution for sedimentation rates is higher.

The sedimentation rates corresponding to the IAII15 sampling point shows the least intake, the values ranging

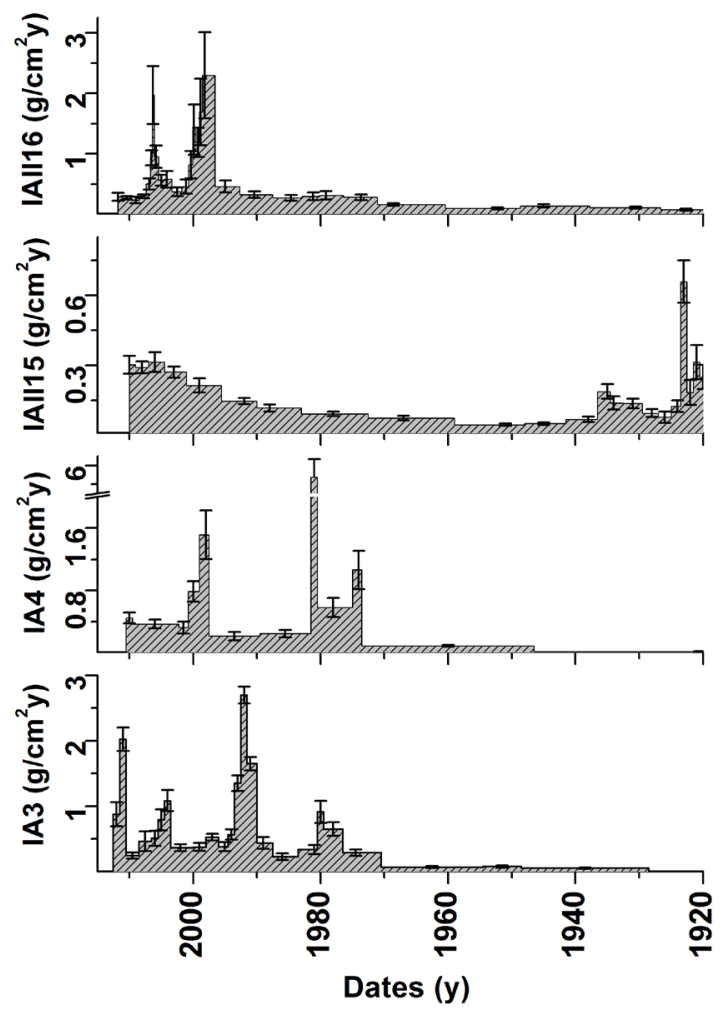

Fig. 13. The mass sedimentation rates of the Lake lacob cores. up to $0.61 \pm 0.18 \mathrm{~g} / \mathrm{cm}^{2} \mathrm{y}$, while the highest values were recorded in the 1948-1952 period. An increase in the sedimentation rates is visible after 1973, the values increasing by up to 5.2 times until 2013. In case of IAII16, two peaks are visible, i.e. in 1998-2000 and 2004-2008.

The peaks recorded in 1974 and 1980, visible in three of the sediment cores (IA3, IA4 and IAII16), show a gradual sedimentation decrease starting in 1972, when the Iron Gates hydroelectric power station was built, from $0.418 \pm 0.14$ to $0.376 \pm 0.1 \mathrm{~g} / \mathrm{cm}^{2} \mathrm{y}$, and if a longer period is used for calculation, between 1972-1989, the average decreased to $0.2 \pm 0.08 \mathrm{~g} / \mathrm{cm}^{2} \mathrm{y}$, which is almost half the sediment levels. This artificial dam also has a sedimentintake-regulating function, since floods with discharges over $11,000 \mathrm{~m}^{3} / \mathrm{s}$ were registered once a year in the 1974 1982 period.

\section{Lake Isac}

According to the sampling points, the cores can be grouped into two areas: samples ISII9 and ISII10 from the north-eastern part of the lake, close to the entry channel, and IS11 and IS12 from the south-eastern part, close to the Uzlina entry channel.

For IS11, the mean mass sedimentation was $0.45 \mathrm{~g} / \mathrm{cm}^{2} \mathrm{y}$. Five peaks are visible: in 2014, 2001, 1998, 1991-1994 and 1988. The deposited mass sedimentation quantity shows that the 1991-1993 flooding period was the most significant $\left(0.82 \pm 0.07 \mathrm{~g} / \mathrm{cm}^{2} \mathrm{y}\right)$ (Fig. 14). In the IS12 core, the 1991-1993 flooding period is not apparent because of the sharp increase in the mass sedimentation rate from the early 1980s, forming a high range of peaks which had three maxima. Comparing the 1986 data to the 1978-1980 sedimentation rates, these increased to double the values, and the average of the mass sedimentation rate was $0.63 \pm 0.05 \mathrm{~g} / \mathrm{cm}^{2} \mathrm{y}$. It is clear that because it was closer to the entry channel, the mean of the mass sedimentation in the IS12 core was $28 \%$ higher than that of IS11. In the ISII9 case before 1980, the mass sedimentation rate was relatively constant at $0.11 \pm 0.01 \mathrm{~g} / \mathrm{cm}^{2} \mathrm{y}$. After 1980, this constant value increased sharply to $0.51 \pm 0.06 \mathrm{~g} / \mathrm{cm}^{2} \mathrm{y}$ from $0.06 \pm 0.01 \mathrm{~g} / \mathrm{cm}^{2} \mathrm{y}$ and 15 years later the sedimentation rate increased by a further 4.3 times, the maximum of $3.95 \pm 0.06 \mathrm{~g} / \mathrm{cm}^{2} \mathrm{y}$ being observed in 2002. In the ISIII 10 core, the sedimentation rate decreased in 1950 to $0.13 \pm 0.01 \mathrm{~g} / \mathrm{cm}^{2} \mathrm{y}$ from $0.86 \pm 0.12$ $\mathrm{g} / \mathrm{cm}^{2} \mathrm{y}$ recorded ten years before. After the $1970 \mathrm{~s}$ the sedimentation rate decreased from $0.61 \pm 0.14 \mathrm{~g} / \mathrm{cm}^{2} \mathrm{y}$ to $0.22 \pm 0.03 \mathrm{~g} / \mathrm{cm}^{2} \mathrm{y}$; this year the Iron Gates hydroelectric power station was built. In this core average the mass sedimentation rate was $0.43 \pm 0.03 \mathrm{~g} / \mathrm{cm}^{2} \mathrm{y}$.

The entire sediment core shows increases in the sedimentation rates after 1980, because of the increase in tree felling, which has a direct proportional effect on sediment accumulation. In the ISII10 core it is shown that the sedimentation rate decreased drastically and was in the 0.14 $0.22 \mathrm{~g} / \mathrm{cm}^{2} \mathrm{y}$ range until 2014. The increases in the ISII9 sedimentation rates happened simultaneously with the 


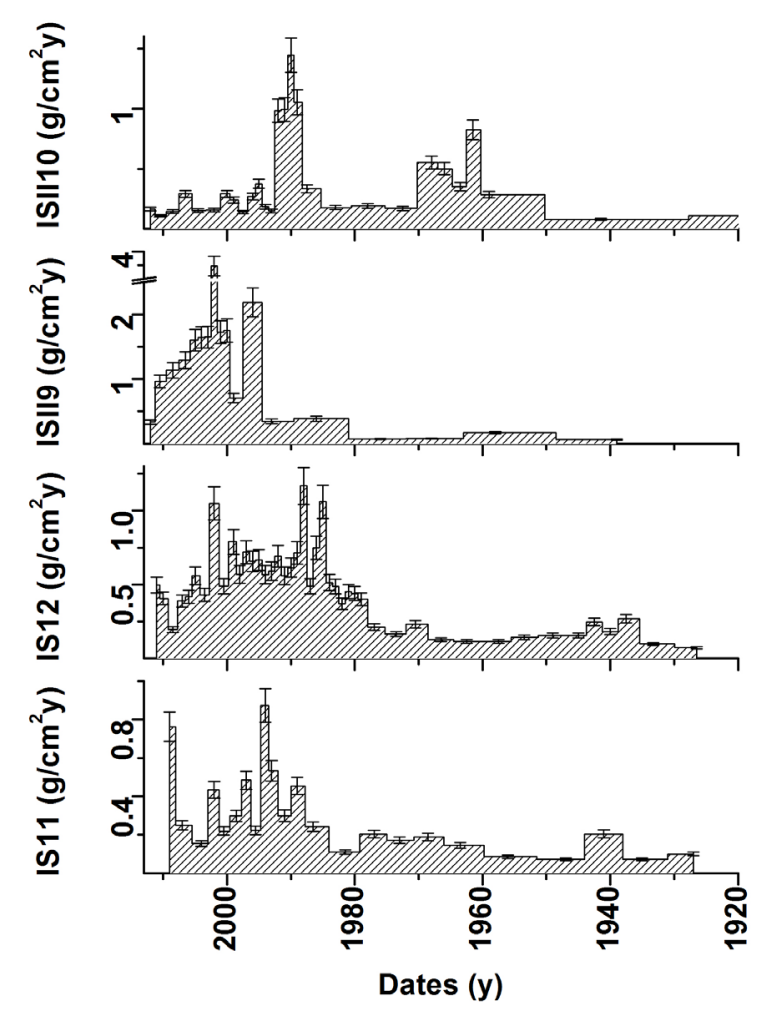

Fig. 14. The mass-sedimentation rates of the Lake Isac cores.

decreases of the sedimentation rates in the ISII10 sampling point.

This could have been due to the fact that until the 1990s the western part of the entrance to the north-eastern channel was more exposed to sediment deposition than the eastern part, the continuously deposited sediment building a natural barrage overtime. After 1990, the majority of the incoming sediment started to settle in the eastern part of the lake.

\section{Heavy metal concentrations}

Heavy metal concentration measurements were carried out on the IA 3 sediment core situated in the south, at the main inflow of the lake. The concentrations of the lowest sediment layer are considered to be those of marine substrate, these values being compared with those measured in higher levels.

The average heavy metal and mineral concentrations were as follows: $16.933 \mathrm{ppm} \mathrm{Li}, 3.955 \% \mathrm{Mg}, 10.726 \%$ $\mathrm{Al}, 2.275 \% \mathrm{~K}, 28.554 \mathrm{ppm} \mathrm{Cr}, 291.408$ ppm Mn, 14.09\% Fe, 6.006 ppm Co, 14.924 ppm Ni, 22.883 ppm Cu, 8.289 ppm As, 401.883 ppb Cd, and 245.45 ppb Hg. In the case of $\mathrm{Zn}$ and $\mathrm{Pb}$, half the measured samples were below the limit of detection, their highest values being $78.469 \mathrm{ppm}$ and $11.575 \mathrm{ppm}$ respectively. The obtained results are on average 3-4 times higher than the values measured in the water during the 2005-2009 period by the Black Sea Scientific Network, but are significantly lower than the values measured in the marine substrate.

As, Cd, Co, Cr, Hg and Ni started to appear in 1980 (Fig. 10), when the Danube Delta received a great amount of sediment (confirmed by the high sedimentation rates in the 1974-1982 period). The metallurgical industry in Romania was the most flourishing in the 1950 1982 period, when 6 metallurgical factories were constructed, one of them being at the edge of the Danube Delta, in Tulcea Slatina. The decreasing heavy metal content in the 1990s can be an indicator of the failure of industrial production due to political changes in eastern Europe and Romania starting in the 1987-1989 period. With the decline of the metallurgical industry, the heavy metal movements were not over: as can be seen in Fig. 15, in some cases this decrease is present only after 1995 , which can be influenced by the heavy metal dissolution of polluted soils and the decomposition of contaminated vegetation. The $\mathrm{Cd}$ shows a relative consistency, with an average of $548 \pm 61 \mathrm{ppb}$. This value is normal compared to the $\mathrm{Cd}$ concentration from most soils worldwide, which does not exceed 1.0-1.1 ppm (Kabata-Pendias 2001), while the values of $\mathrm{Hg}$ and $\mathrm{Pb}$ seemed to be increasing in the upper layers of the sediment core. The increased $\mathrm{Pb}$ concentration was caused by the increases in the $\mathrm{Pb}$ releases in the 2010-2013 period to 5.4 tonnes/y, whereas in the 2005-2010 period it was only 1.70.3 tonnes/y (ANPM report, 2013). The anthropogenic sources of $\mathrm{Pb}$ can be traffic, metallurgical mining, batteries, old lead-based paints, and sewage sludge (Salminen et al., 2005). Cr, Co and Ni show lower values compared to the (on average) 1.45 times higher values registered in the 1980-1995 period. In the case of As, concentrations show a decreasing trend compared to the 14 ppb measured in the marine substrate, the values reaching $4 \mathrm{ppm}$ by 2013 . The average content of As in soil in the Earth was 6.8 ppm (Kabata-Pendias, 2011).

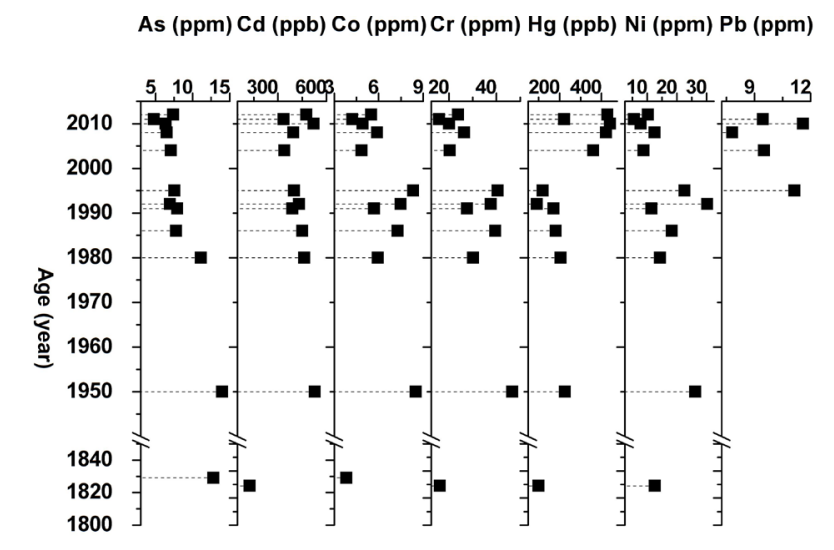

Fig. 15. Heavy metal concentrations in the IA3 core. 


\section{CONCLUSIONS}

The first study for applying the ${ }^{210} \mathrm{~Pb}$ dating method and the ${ }^{137} \mathrm{Cs}$ validation was carried out on Lake Isac and Iacob from the Danube Delta, Romania. These lakes were assessed the first time due to alpha and gamma spectrometric measurements, which were carried out to measure the radionuclides of interest $\left({ }^{210} \mathrm{~Pb} /{ }^{210} \mathrm{Po},{ }^{226} \mathrm{Ra}\right.$ and $\left.{ }^{137} \mathrm{Cs}\right)$ in the Danube deltaic sediments. The geochronology of the sediment layers was generated and sedimentation rates were assessed in order to determine the dynamics of the sedimentation processes involved in the evolution of the Danube Delta, and, more precisely, Lake Iacob The reconstruction of heavy metal concentrations in each sediment layer was also made in the case of the IA3 sediment core.

The low OM content meant, that the increases in the sedimentation rates in these cases had no correlation with the decaying organic matter, but with the quantity of sediment transported by the Danube. The results show that mean sedimentation rates in case of Lake Iacob were $0.51 \pm 0.08$, with a max. of $3.84 \pm 0.05$ and a min. of $0.03 \pm 0.01 \mathrm{~g} / \mathrm{cm}^{2}$. In the case of Lake Isac the mass sedimentation average was $0.58 \pm 0.09 \mathrm{~g} / \mathrm{cm}^{2}$, the maximum being $3.95 \pm 0.06 \mathrm{~g} / \mathrm{cm}^{2} \mathrm{y}$ and the minimum $0.02 \pm 0.01$ $\mathrm{g} / \mathrm{cm}^{2} \mathrm{y}$. A quasi-similar pattern in the sedimentation rates can also be found in the water, and the sediment in- and out-flow behind Iron Gate 2, which correspond to major flooding events from the previous 50 years, where discharges of over $10,000 \mathrm{~m}^{3} / \mathrm{s}$ were measured in the catchment areas of the Danube Delta.

The sedimentation rates can be divided into four major periods: 1940-1972 (1972 is the date of the construction of the Iron Gates), 1972-1980, 1972-1989 (the period until the regime changes in Romania), and 1989-2013. In the case of Lake Iacob in the first period the average sedimentation rate was $0.418 \mathrm{~g} / \mathrm{cm}^{2} \mathrm{y}$, in the second it slowly decreased to $0.376 \mathrm{~g} / \mathrm{cm}^{2} \mathrm{y}$, and in the third period it decreased to $0.209 \mathrm{~g} / \mathrm{cm}^{2} \mathrm{y}$, which means a retention of $27.3 \%$ of the sediment after the IG power-plant construction. In the case of Lake Isac, the changes are more visible: in the first period the sedimentation rate had an average of $0.446 \mathrm{~g} / \mathrm{cm}^{2} \mathrm{y}$, and in the second it decreased to $0.197 \mathrm{~g} / \mathrm{cm}^{2} \mathrm{y}$, which means a $42.35 \%$ retention of sediment. After that, in the third period, the sedimentation slowly increased to $0.269 \mathrm{~g} / \mathrm{cm}^{2} \mathrm{y}$. In the last period, in both the lakes, a big increase in the sedimentation rate is visible in Lake Iacob - by more than three times $\left(0.677 \mathrm{~g} / \mathrm{cm}^{2} \mathrm{y}\right)-$ and in Lake Isac by more than twice $\left(0.715 \mathrm{~g} / \mathrm{cm}^{2} \mathrm{y}\right)$.

Flooding after 1980 can only be observed in Lake Iacob, because of the Mahmudia meander cutting into the Sf. Gheorghe branch in the 1984-1988 period (Tiron et al., 2009). These are not as visible in the sedimentation rates of Lake Isac - only the IS11 sediment cores show the end of the 1980 flooding period. The mentioned channel cutting is responsible for the increased sedimentation rates starting from 1981 in the IS12 core area.

After the 1970s the sedimentation rate decreased from $0.61 \pm 0.14 \mathrm{~g} / \mathrm{cm}^{2} \mathrm{y}$ to $0.22 \pm 0.03 \mathrm{~g} / \mathrm{cm}^{2} \mathrm{y}$, when the Iron Gates hydroelectric power station was built. However, not every sediment core is suitable for the assessment of effects, since a series of other factors (flooding, precipitation quantity, storms, various human interventions etc.) can also influence the sedimentation rates.

A sudden decrease in the total ${ }^{210} \mathrm{~Pb}$ content, and stagnation in the age/depth correlation, can be an indicator of a high sediment-intake quantity, as it is in the case of IAII15. The total ${ }^{120} \mathrm{~Pb}$ concentration had an average of $37 \mathrm{~Bq} / \mathrm{kg}$ in the $19-55 \mathrm{~cm}$ range and the ages for this period were calculated at $1980 \pm 2 \mathrm{y}$, while masssedimentation rates show an average of $1.92 \pm 0.34$ $\mathrm{g} / \mathrm{cm}^{2} \mathrm{y}$ (compared to the $0.68 \pm 0.13 \mathrm{~g} / \mathrm{cm}^{2} \mathrm{y}$ average in the core).

The heavy metal concentrations were on average higher than the values measured in the marine substrate (the exception being As). The results are on average 3.36 times higher than the values measured in the water during the 2005-2009 period by the Black Sea Scientific Network. $\mathrm{Pb}$ contamination is visible only from the beginning of the $1990 \mathrm{~s}$, when the $\mathrm{Pb}$ based fuel was introduced, while $\mathrm{Hg}$ concentrations only started to grow after 2000. Ni, Cd, Co and As started decreasing after 1995, since industry had a marked decline after 1989, when some of the major mines and factories were closed down because of the changes in the political regime.

\section{ACKNOWLEDGMENTS}

This work was supported by the Ministry of National Education, Romania, under grant 61/30.04.2013, for the PN-II-RU-TE-2011-3-0351 project.

\section{REFERENCES}

Al-Masri M, Aba A, Khalil H and Al-Hares Z, 2002. Sedimentation rates and pollution history of a dried lake: Al-Oteibeh Lake. Science of the Total Environment 293(1-3): 177-189, DOI 10.1016/S0048-9697(02)00013-X.

Alvisi F and Dinelli E, 2002. Evolution of sediment composition of the coastal Lake San Puoto (Latium, Italy) in the last two centuries. Journal of Limnology 61(1): 15-26.

ANPM raport, 2013. Raport privind starea mediului Official site of the National Environmental Protection Agency, www.anpm.ro

Appleby PG, 2001. Chronostratigraphic techniques in recent sediments. Tracking Environmental Change Using Lake Sediments 1: 171203.

Babic Mladenovic M, Kolarov V and Damjanovic V, 2013. Sediment regime of the Danube River in Serbia, International Journal of Sediment Research 28(4): 470-485, DOI 10.1016/S10016279(14)60006-8.

Bačeva K, Stafilov T, Šajn R, Tănăselia C and Popov SI, 2011. Distribution of chemical elements in attic dust in the vicinity of ferronickel smelter plant. Fresenius Environmental Bulletin 20: $2306-$ 2314.

Baskaran M, Miller C, Kumar A, Andersen E, Hui J, Selegean P, Creech CT and Barkach J, 2015. Sediment accumulation rates and 
sediment dynamics using five different methods in a wellconstrained impoundment: Case study from Union Lake, Michigan. Journal of Great Lakes Research 41: 607-617, DOI 10.1016/j.jglr.2015.03.013.

Begy RC, Simon H and Reizer E, 2015a. Efficiency testing of Red Lake protection dam on Rosu stream by ${ }^{210} \mathrm{~Pb}$ method. Journal of Radioanalytical and Nuclear Chemistry 303(3): 2539-2545, DOI 10.1007/s10967-014-3684-y.

Begy RC, Dumitru OA, Simon H and Steopoaie I, 2015b. An improved procedure for the determination of ${ }^{210} \mathrm{Po}$ by alpha spectrometry in sediments samples from Danube Delta. Journal of Radioanalytical and Nuclear Chemistry 303(3): 2553-2557, DOI 10.1007/s10967014-3703-z.

Hakanson L, 1977. An empirical model for physical parameter of recent sedimentary deposit of lake Ekoln and Lake Vanera. Vatten 3: 266-289.

Hou Q, Yang Z, Ji J, Yu T, Chen G, Li J, Xia X, Zhang M and Yuan X, 2014. Annual net input fluxes of heavy metals of the agroecosystem in the Yangtze River delta, China. Journal of Geochemical Exploration 139: 68-84, DOI 10.1016/j.gexplo.2013.08.007.

Humphries MS, 2010. ${ }^{137} \mathrm{Cs}$ and ${ }^{210} \mathrm{~Pb}$ derived sediment accumulation rates and their role in the long-term development of the Mkuze River floodplain, South Africa. Geomorphology 119: 88-96, DOI 10.1016/j.geomorph.2010.03.003.

Kabata-Pendias, 2001. Trace Elements in Soils and Plants. CRC press LLC, USA

Kabata-Pendias, 2011. Trace Elements in Soils and Plants. CRC Press, fourth edition $543 \mathrm{p}$.

Larsen J, Appleby P, Christensen G, Berg T and Eide I, 2010. Historical and Geographical Trends in Sediment Chronology from Lakes and Marine Sites Along the Norwegian Coast. Water Air Soil Pollution 206: 237-250, DOI 10.1007/s11270-009-0099-4.

Manger E, 1963. Porosity and bulk density of sedimentary rocks. Geological survey bulletin 1144-E.

Moore WS, 1984. Radium isotope measurements using germanium detectors. Nuclear instrument and methods in physics research 223: 407-411, DOI 10.1016/0167-5087(84)90683-5.

Niencheski L, Moore W and Windom H, 2014. History of human activity in coastal southern Brazil from sediment. Marine Pollution Bulletin 78: 209-212, DOI 10.1016/marpolbul.2013.10.042.

Oosterberg W, Staras M, Bogdan L, Buijse AD, Constantinescu A, Coops H, Hanganu J, Ibelings BW, Menting GAM, Nãvodaru I, Török L, 2000. Ecological Gradients in the Danube Delta - Present State and Man-Induced Changes. RIZA Report Nr. 2000.015, RIZA the Netherlands, DDNI Romania and Danube Delta Biopshere Reserve Authority: 166 pp.

Qi S, Leipe T, Rueckert P, Di Z and Harff J, 2010. Geochemical sources, deposition and enrichment of heavy metals in short sedi ment cores from the Pearl River Estuary, Southern China. Journal of Marine Systems 82: S28-S42, DOI 10.1016/j.jmarsys.2010.02.003.

Salminen R, Batista MJ, Bidovec M, Demetriades A, Vivo de B, Vos W, Duris M, Gilucis A, Gregorauskiene V, Halamic J, Heitzmann P, Lima A, Jordan G, Klaver G, Klein P, Lis J, Locutura J, Marsina K, Mazreku A, O'Connor PJ, Olsso SÅ, Ottesen RT, Petersell V, Plant JA, Reeder S, Salpeteur I, Sandström H, Siewers U, Steenfeld A and Tarvainen T, 2005. Geochemical Atlas of Europe. Part. 1 - Background Information, Methodology and Maps. EuroGeoSurveys $525 \mathrm{p}$.

Saravana Kumar U, Navada SV, Rao SM, Nachiappan RmP, Kumar B, Krishnamoorthy TM, Jha SK and Shukla VK, 1999. Determination of recent sedimentation rates and pattern in Lake Naini, India by $210 \mathrm{~Pb}$ and $137 \mathrm{Cs}$ dating techniques. Applied Radiation and Isotopes 51(1): 97-105, DOI 10.1016/S0969-8043(98)00148-1.

Schneider L, Maher W, Potts J, Gruber B, Batley G, Taylor A, Chariton A, Krokowa F, Zawadzki A and Heijnis H, 2014. Recent history of sediment metal contamination in Lake Macquarie, Australia, and an assessment of ash handling procedure effectiveness in mitigating metal contamination from coal-fired power stations. Science of the Total Environment 490: 659-670, DOI 10.1016/j.scitotenv.2014.04.055.

Sert I, Yener G, Ozel E, Pekcetinoz B, Eftelioglu M and Gorgun AU, 2012. Estimation of sediment accumulation rates using naturally occuring $210 \mathrm{~Pb}$ models in Gülbahçe Bay, Aegean Sea, Turkey. Journal of Environmental Radioactivity 107: 1-12, DOI 10.1016/j.jenvrad.2011.11.002.

Steiner B, Hanselmann K and Krähenbühl U, 2000. Dating and heavy metal contents of sediment cores of a high-alpine, remote lake: Jörisee (Switzerland). International Journal of Environmental Analytical Chemistry 78(2): 131-148, DOI 10.1080/03067310008044406.

Szmytkiewicz A and Zalewska T, 2014. Sediment deposition and accumulation rates determined by sediment trap and $210 \mathrm{~Pb}$ isotope methods in the Outer Puck Bay (Baltic Sea). Oceanologia 56: 85106, DOI 10.5697/oc.56-1.085.

Tiron LJ, Le Coz J, Provansal M, Panin N, Raccasi G, Dramais G and Dussouillez P, 2009. Flow and sediment processes in a cutoff meander of the Danube Delta during episodic flooding. Geomorphology 106: 186-197, DOI 10.1016/j.geomorph.2008.10.016.

United Nations, 2008. Sources and Effects of Ionizing Radiation, 2 vols, United Nations, New York

Xu Z, Salem A, Chen Z, Zhang W, Chen J, Wang Z, Sun Q and Yin D, 2008. $\mathrm{Pb}-210$ and Cs-137 distribution in Burullus lagoon sediments of Nile river delta, Egypt: sedimentation rate after Aswan High Dam. Frontiers of Earth Science 2(4): 434-438. 